\title{
Impact of the copepod Mytilicola orientalis on the Pacific oyster Crassostrea gigas in Ireland
}

\author{
S. Steele ${ }^{1, *}$, M. F. Mulcahy ${ }^{2}$ \\ ${ }^{1}$ Marine Research Services Ltd, 38 Middle Hill, Egham, Surrey TW20 OJL, United Kingdom \\ ${ }^{2}$ Department of Zoology and Animal Ecology, National University of Ireland Cork, Cork, Ireland
}

\begin{abstract}
Infections of a population of Crassostrea gigas by the copepod Mytilicola orientalis were examined at an oyster growing site at Dungarvan, County Waterford, Ireland. Twenty-one samples, each consisting of 20 to 30 oysters have been examined over 2 yr. Condition, sex, reproductive stage, length, weight, glycogen content and other parasite burdens of the oysters were examined in relation to the degree of infection of $M$. orientalis; $14.38 \%$ of oysters were infested. Mean abundance was 0.6 oyster $^{-1}$. The maximum number of copepods in an oyster was 20. M. orientalis had no effect on condition, growth, sex, stage or glycogen content of the oyster but correlated with shell burrowing by Polydora sp.
\end{abstract}

KEY WORDS: Crassostrea gigas $\cdot$ Mytilicola orientalis $\cdot$ Copepod

Resale or republication not permitted without written consent of the publisher

\section{INTRODUCTION}

Following implementation of European Commission Directive 91/67/EEC leading to free movement of stocks of Crassostrea gigas, the intestinal copepod Mytilicola orientalis (Mori) (Copepoda: Cyclopoida) was discovered in several locations around the Irish coastline (De Grave et al. 1995). M. orientalis is native to Korea and Japan and is present in the guts of many bivalve species, with original Asian hosts including the Pacific oyster (Grizel 1985). M. orientalis was introduced to the Pacific coast of the USA with shipments of Japanese oysters as early as 1938 (Carlton 1979). The copepod was first reported in Europe by His (1977) and was suspected to have been introduced from either Japan or British Columbia. The introduction of $M$. orientalis to Ireland with the import of Pacific oysters in 1993 led to alarm at the potential damage to the Irish Pacific oyster industry. Pacific oyster culture in Ireland is an important industry producing more than 6000 tonnes of oysters annually. As the oyster does not usually reproduce successfully in these waters, the indus-

*E-mail: stlsus@yahoo.com try relies on spat supplied from France or from hatcheries and grown to market size on a trestle system. This study examines oysters from Dungarvan, County Waterford, monthly over a period of $2 \mathrm{yr}$ to examine effects of the parasite on condition, sex, reproductive stage, length, weight and biochemical composition of the oysters and shell damage by Polydora sp.

\section{MATERIALS AND METHODS}

Sampling period. Oysters were supplied as parasite free seed from Guernsey Sea Farms, Guernsey, UK. Oysters were $2 \mathrm{yr}$ old at the start of the trial. Dates were recorded as Julian Days with 1 January 1996 as Day 1. The oysters were grown on trestles. From April 1996 until December 1997, monthly samples of between 20 and 30 oysters were collected from Dungarvan. All samples were taken from the same trestles to minimise differences caused by shore positioning.

Parasites and pathology. Occurrence of parasites in oysters was noted, as were any abnormalities. The digestive tract of oysters was dissected, Mytilicola orientalis numbers were recorded and specimens were fixed in $70 \%$ alcohol. Polydora sp. infection was 
classed as mild ( $<25 \%$ inner shell coverage) or severe ( $>25 \%$ shell coverage). Each oyster had an individual record for all parameters, allowing the determination of relationships between levels of infection of copepods, condition index and morphometrics on levels of development.

Histological techniques. Histological methods were the same as those used earlier (Steele \& Mulcahy 1999). The oysters were classified into distinct phases of gonadal maturity based on the observations made: undifferentiated (Stage 0), developing (Stages 1 and 2), ripe (Stage 3), partially spent (Stage 4), totally spent (Stage 5), post spawning (Stage 6) and resorbing (Stage 7). The criteria taken for the classification are modifications of the staging system used by Mann (1979).

Condition indices. Soft tissues, removed from the shells, were blotted and weighed to obtain total wet weight and then were dissected for histology. The remaining tissues were weighed to obtain partial wet weight, dried at $60^{\circ} \mathrm{C}$ for $48 \mathrm{~h}$, then re-weighed (partial dry weight). The resulting wet:dry ratio was used to estimate the total dry tissue weight (Fisher et al. 1996) The condition index was calculated as in Crosby \& Gale (1990):

Condition index $=\frac{\text { dry soft tissue }(g) \times 1000}{\text { internal shell cavity capacity }(g)}$

The shell cavity capacity of a bivalve is determined by subtracting dry shell weight $(\mathrm{g})$ in air from the total whole live weight of the oyster. Crosby \& Gale (1990) find that this method yields indices that assess the proportion of available internal cavity capacity used by a bivalve's soft body tissues. This allows comparison between metabolism directed towards calcification processes and metabolism directed towards somatic and gametic processes.

Glycogen content. While frozen, oysters were dissected and adductor muscle and gonad/mantle tissue were removed. This tissue was held at $-40^{\circ} \mathrm{C}$ before freeze drying. Expression of glycogen is in $\mathrm{mg} \mathrm{mg}^{-1}$ of dry tissue. Determinations, including glycogen content, were made in triplicate and coefficients of variation among the replicates were not allowed to exceed $5 \%$. Results were determined for each oyster.

A modification of the method of Dubois et al. (1956) for microtitre plate reading was used for glycogen analysis. Results were calibrated against standard curves of oyster glycogen content (Sigma Chemical Co., St. Louis, MO, Type II).

Statistical analysis. A 1-sample $t$-test was used to ascertain differences between condition indices, temperatures and chlorophyll a levels in the 2 sites. The Kendall rank-order correlation coefficients (Zar 1984) were calculated to ascertain the degree of association among temperature, shell length, sample date, infection of parasites, sex, stage of maturity and condition indices at the 2 sites. Kendall's coefficient is a nonparametric measure of association for ordinal or ranked variables that takes ties into account.

\section{RESULTS}

\section{Parameters of host population}

At the start of the study, oysters in Dungarvan measured (mean $\pm \mathrm{SE}$ ) $9.2 \pm 0.27 \mathrm{~cm}$ and weighed $64.32 \pm$ $3.15 \mathrm{~g}$. By the end of the study, in December 1997, oysters measured $11.60 \pm 0.233 \mathrm{~cm}$ and weighed $140.06 \pm$ $7.72 \mathrm{~g}$.

\section{Prevalence and abundance of infection}

In Dungarvan $14.38 \%$ of oysters were infested with Mytilicola orientalis $(\mathrm{N}=848)$. $M$. orientalis averaged 0.6 oyster $^{-1}(\mathrm{~N}=848)$. A maximum of $20 \mathrm{M}$. orientalis was recorded in an individual. Prevalence of infection ranged from 0 to $29 \%$ (Fig. 1, Table 1). The level of prevalence increased from the first year to the second year. The mean abundance was $12.28 \%$ during 1996 and $18.44 \%$ during 1997 . The abundance also

Table 1. Prevalence of Mytilicola orientalis and Polydora sp. in Crassostrea gigas from Dungarvan, Southern Ireland. $\mathrm{N}$ : number of specimens

\begin{tabular}{|cccc|}
\hline $\mathrm{N}$ & $\begin{array}{c}\text { Oysters infested } \\
\text { with } \begin{array}{c}\text { M. orientalis } \\
(\%)\end{array}\end{array}$ & $\begin{array}{c}\text { Oysters infested } \\
\text { with Polydora sp. } \\
(\%)\end{array}$ & $\begin{array}{c}\text { Julian } \\
\text { Day }\end{array}$ \\
\hline 23 & 8.7 & 26.1 & \\
29 & 10.3 & 27.6 & 111 \\
19 & 0.00 & 57.9 & 161 \\
22 & 18.2 & 77.3 & 229 \\
24 & 20.8 & 79.2 & 257 \\
26 & 7.7 & 92.3 & 275 \\
20 & 10.0 & 85.0 & 286 \\
20 & 10.0 & 95.0 & 316 \\
30 & 13.3 & 73.3 & 350 \\
30 & 10.0 & 83.3 & 389 \\
30 & 16.7 & 76.7 & 405 \\
27 & 29.6 & 85.2 & 432 \\
30 & 13.3 & 70.0 & 464 \\
28 & 17.9 & 85.7 & 492 \\
29 & 27.6 & 89.6 & 520 \\
28 & 10.7 & 100.0 & 550 \\
29 & 27.6 & 93.1 & 578 \\
26 & 11.5 & 76.9 & 627 \\
29 & 24.0 & 72.0 & 654 \\
29 & 14.0 & 100.0 & 683 \\
30 & 00.0 & 97.0 & 714 \\
& & & \\
\hline
\end{tabular}




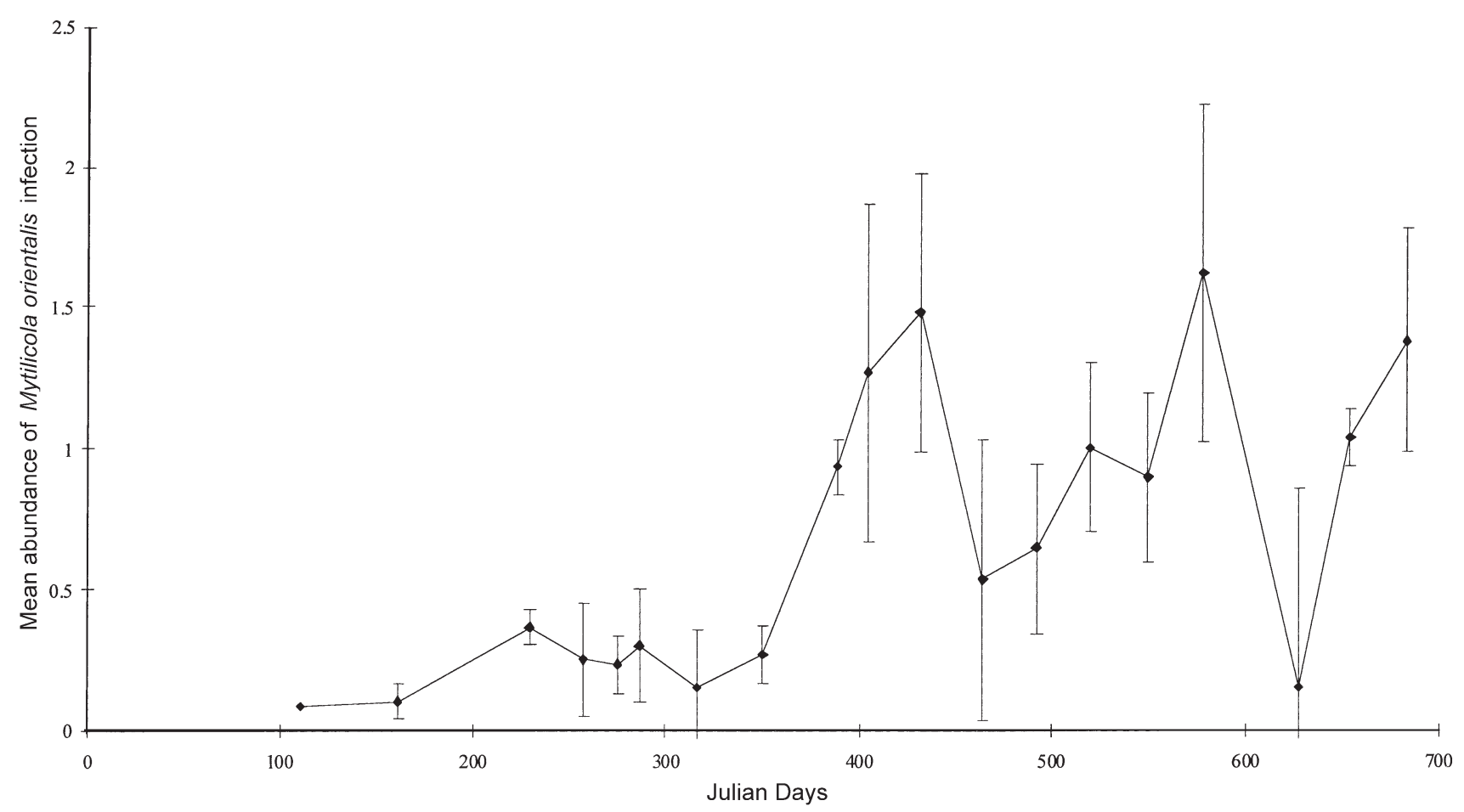

Fig. 1. Mean abundance of Mytilicola orientalis per Crassostrea gigas in Dungarvan Bay over the period of the study. Bars show standard deviation

increased from 0.22 in 1996 to 0.99 in 1997. The increase in copepod numbers occurred in January 1997 (Julian Day 389) and through the spring, with a decrease in number per host over the summer and an increase again in the autumn. This pattern was not as evident in 1996.

\section{Effect on oysters}

A Kendall correlation matrix showed no significant interaction between Mytilicola orientalis and the condition, sex , stage or size of oyster (Table 2). There was no significant correlation of levels of infection with shell length or total wet weight of oyster. $M$. orientalis had no significant effect on condition or on glycogen in either adductor muscle or gonad (Table 3).

\section{Interaction with Polydora sp.}

Polydora sp. infested $73.48 \%$ of oysters (Table 1 ). There was considerable variation in the percentage of oysters infested, ranging from 26 to $100 \%$. There was a significant positive correlation between the prevalence of Mytilicola orientalis and Polydora sp. (Kendall tau-B $=0.095, \mathrm{p}<0.005)$.

\section{DISCUSSION}

In Dungarvan, oysters became infested with Mytilicola orientalis. The oysters were not infested with the close relative Mytilicola intesinalis (Steuer), which is endemic around European coasts (Blateau et al. 1992). There are no records of $M$. intestinalis in Dungarvan. M. intestinalis has been found in Crassostrea gigas in

Table 2. Kendall correlation matrix for infection by Mytilicola orientalis in Crassostrea gigas in Dungarvan. The significance of the coefficient indicates the direction of the relationship, and its absolute value indicates the strength, with larger absolute values indicating stronger relationships. Possible values range from -1 to $1 .{ }^{*}$ Correlation is significant at the 0.05 level (2-tailed)

\begin{tabular}{|lc|}
\hline & M. orientalis infection \\
\hline Condition index & -0.003 \\
Date & 0.050 \\
Shell length & 0.022 \\
Polydora sp. infection & $0.095^{*}$ \\
Sex & 0.042 \\
Stage & -0.029 \\
Temperature & 0.027 \\
Gonad glycogen & -0.056 \\
Adductor glycogen & -0.046 \\
\hline
\end{tabular}


Table 3. Variations in means of chemical components and in condition index in Crassostrea gigas from Dungarvan in adductor muscle and gonad in relation to numbers of Mytilicola orientalis in the flesh of the oyster. CI: condition index; AG: adductor glycogen; GG: gonad glycogen. All chemical results are expressed in mg per $2 \mathrm{mg}$ of dry flesh \pm 1 SE. $\mathrm{N}$ : number of specimens

\begin{tabular}{|c|c|c|c|c|}
\hline \multicolumn{5}{|c|}{ M. orientalis } \\
\hline None & $92.0 \pm 1.58$ & $0.08 \pm 0.00$ & $0.19 \pm 0.01$ & 414 \\
\hline 1 & $92.64 \pm 7.10$ & $0.06 \pm 0.01$ & $0.15 \pm 0.02$ & 21 \\
\hline 2 & $87.63 \pm 7.60$ & $0.06 \pm 0.01$ & $0.21 \pm 0.03$ & 18 \\
\hline 3 & $99.52 \pm 2.67$ & $0.06 \pm 0.01$ & $0.20 \pm 0.05$ & 3 \\
\hline 4 & $95.4 \pm 23.0$ & $0.13 \pm 0.05$ & $0.10 \pm 0.03$ & 5 \\
\hline 5 & $96.8 \pm 19.0$ & $0.10 \pm 0.05$ & $0.14 \pm 0.03$ & 6 \\
\hline 6 & $92.58 \pm 7.01$ & $0.07 \pm 0.02$ & $0.21 \pm 0.011$ & 5 \\
\hline 7 & $69.75 \pm 5.82$ & $0.03 \pm 0.01$ & $0.26 \pm 0.03$ & 4 \\
\hline 8 & $73.95 \pm 6.88$ & $0.11 \pm 0.07$ & 0.13 & 5 \\
\hline 9 & $92.8 \pm 12.6$ & & 0.39 & 2 \\
\hline 10 & & & 0.21 & 1 \\
\hline 12 & 90.86 & 0.04 & 0.12 & 1 \\
\hline 13 & 110.19 & & & 1 \\
\hline 14 & 90.50 & 0.02 & & 1 \\
\hline 15 & $83.66 \pm 19.9$ & 0.03 & 0.05 & 2 \\
\hline 16 & 94.18 & 0.09 & 0.07 & 1 \\
\hline
\end{tabular}

the Exe estuary throughout the year (Aguirre-Macedo \& Kennedy 1999).

Up to 40 Mytilicola have been recorded per oyster (Korringa 1951) but this study found a maximum of 20 copepods per oyster, with a mean abundance of 0.64 . De Grave et al. (1995) found that the mean abundance of $M$. orientalis in Dungarvan in July 1994 was between 1.07 and 1.48, with a maximum infection of 7 copepods per oyster.

Copepod infected $14.4 \%$ of oysters. In other European oyster populations $36 \%$ of oysters have been found to be affected (His 1977).

This study found that infection with Mytilicola orientalis did not affect condition indices. Opinions vary on the impact of Mytilicolidae on condition, from no effect to causing massive mortalities. De Grave et al. (1995) also found that the abundance of $M$. orientalis infection did not significantly affect condition indices in Dungarvan. Neither His (1977) nor Bernard (1969) found a significant effect on fatness (Deslous-Paoli 1981). Katkansky et al. (1967) consider that at least 5 M. orientalis are necessary to provoke an effect on the condition. Korringa (1951) found no effect with fewer than 3 copepods, as did Deslous-Paoli (1981).

There was no association between Mytilicola orientalis infection and the sex and stage of the oysters in this study. In contrast, Mann (1956) showed that in mussels, there is a 10 to $20 \%$ loss of gonad. Williams (1969) found reduced gonad size and possible retarded spawning due to infection in mussels.
There was a significant positive relationship between numbers of Mytilicola orientalis and abundance of infection by Polydora. In contrast in mussels, Williams (1969) found that Polydora caused a decreased rate of parasitism by the copepod $M y-$ tilicola intestinalis in Mytilus edulis, possibly due to lack of food as more energy is put into shell repair when shells are infested by Polydora. Further work needs to be undertaken in oysters to look at resource partitioning to explain why there is a positive relationship. There may be evidence of co-evolution of species with the host Crassostrea gigas. Co-evolution may also explain the lack of an effect of $M$. orientalis on a host species (Grizel 1985).

Williams (1969), studying the effect of Mytilicola intestinalis on the chemical composition of Mytilus edulis, found no significant difference in chemical concentrations between parasitised and non-parasitised mussels. However, chemical changes in parasitised mussels occurred later than in non-parasitised mussels. He suggests that $M$. intestinalis plays a role in the inhibition of neurosecretory material from the cerebral ganglion, with the resulting later release of gametes in infected mussels. Deslous-Paoli (1981) found that more than 3 Mytilicola orientalis in Crassostrea gigas induced a significant decrease in concentrations of carbohydrates and glycogen. This may be because the presence of $M$. orientalis in quantity in the intestinal tract of molluscs can interrupt the intestinal transit and cause an alimentary spoilation (His 1977). This spoilation is thought to induce a decrease of energetic reserves, constituted mainly by glycogen (Deslous-Paoli \& Heral 1988). A loss of glycogen was not found in the present study; however, many studies find that parasites have a noticeable impact on the host only in times of low food availability and other stresses (Hepper 1955, His 1977).

In conclusion, this study found that over $2 \mathrm{yr}$ in a population of Crassostrea gigas there were no effects of Mytilicola orientalis on the Pacific oyster.

\section{LITERATURE CITED}

Aguirre-Macedo ML, Kennedy CR (1999) Diversity of metazoan parasites of the introduced oyster species in Crassostrea gigas in the Exe estuary. J Mar Biol Assoc UK 79: $57-63$

Bernard FR (1969) The parasitic copepod Mytilicola orientalis in British Columbia bivalves. J Fish Res Board Can 261: 190-191

Blateau D, Le Coquic Y, Mialhe E, Grizel H (1992) Mussel (Mytilus edulis) treatment against the red copepod Mytilicola intestinalis. Aquaculture 1072(3):165-169 
Carlton JT (1979) Biogeographical ecology of the introduced marine and estuarine invertebrates of the Pacific coast of North America. University of California, Davis

Crosby MP, Gale LD (1990) A review and evaluation of bivalve condition index methodologies with a suggested standard method. J Shellfish Res 91:233-237

De Grave S, Xie Q, Casey D (1995) The intensity of infection by the intestinal copepod, Mytilicola orientalis, does not affect the condition of Pacific oysters (Crassostrea gigas). Bull Eur Assoc Fish Pathol 154:129-131

Deslous-Paoli JM (1981) Mytilicola orientalis Mori, Crassostrea gigas Thunberg's parasite in the basin of Marennes-Oleron: impact on the condition and biochemical composition of oysters during rearing. ICES CM 1981/K:29

Deslous-Paoli JM, Heral M (1988) Biochemical composition and energy value of Crassostrea gigas (Thunberg) cultured in the bay of Marennes-Oleron. Aquat Living Resour $1: 239-249$

Dubois M, Gilles KA, Hamilton JK, Rebers PA, Smith F (1956) Colorimetric method for determination of sugars and related substances. Anal Chem 283:350-353

Fisher WS, Oliver JM, Edwards P (1996) Hematologic and serologic variability of eastern oysters from Apalachicola bay, Florida. J Shellfish Res 153:555-564

Grizel H (1985) Mytilicola orientalis MORI, parasitism parasitose a Mytilicola orientalis. MORI. In: Sindermann DJ (ed) Fiches d'identification des maladies et parasites des poissons, crustaces et mollusques. Conseil international pour l'exploration de la mer, Copenhagen, p 1-4

Editorial responsibility: Wolfgang Körting,

Hannover, Germany
Hepper BT (1955) Environmental factors governing the infection of mussels by Mytilicola intestinalis. Fishery investigations. Min Agricult Fish Food 203:1-21

His E (1977) Observations preliminaires sur la presence de Mytilicola orientalis MORI chez Crassostrea gigas Thunberg dans le Bassin d'arcachon. Bull Soc Geol Amis Mus Havre LXIV2:7-9

Katkansky SC, Sparks AK, Chew KK (1967) Distribution and effects of the endoparasitic copepod, Mytilicola orientalis on the Pacific oyster, Crassostrea gigas, on the Pacific coast. Proc Natl Shellfish Assoc 57:50-58

Korringa P (1951) Le Mytilicola intestinalis Steuer (Copepoda Parasitica) menance l'industrie mouliere en Zelande. Rev Trav Off Sci Peches Marit 17:9-13

Mann H (1956) The influence of Mytilicola intestinalis (Copepoda parasitica) on the development of the gonads of Mytilus edulis. Rapp PV Reun Cons Int Explor Mer 140: $57-8$

Mann R (1979) Some biochemical and physiological aspects of growth and gametogenesis in Crasssostrea gigas and Ostrea edulis grown at sustained elevated temperatures. J Mar Biol Assoc UK 59:95-110

Steele S, Mulcahy MF (1999) Gametogenesis of the oyster Crassostrea gigas in Southern Ireland. J Mar Biol Assoc UK 79:673-686

Williams CS (1969) The effect of Mytilicola intestinalis on the biochemical composition of mussels. J Mar Biol Assoc UK 49:164-173

Zar JH (1984) Biostatistical analysis. Prentice-Hall, Englewood Cliffs

Submitted: May 7, 2001; Accepted: July 15, 2001

Proofs received from author(s): November 1, 2001 